\title{
The Typology of Motion Expressions in English, Japanese, and Persian: Reconsidering the Cline versus Typology Debate Based on Heading
}

\author{
Parimah Javanmardi, Ryan Spring, Satoshi Uehara \\ Graduate School of International Cultural Studies, Tohoku University, Sendai, Japan \\ Email: parimah.javanmardi@yahoo.com, spring.ryan.edward.c4@tohoku.ac.jp, uehara@tohoku.ac.jp
}

How to cite this paper: Javanmardi, P., Spring, R., \& Uehara, S. (2022). The Typology of Motion Expressions in English, Japanese, and Persian: Reconsidering the Cline versus Typology Debate Based on Heading. Open Journal of Modern Linguistics, 12, 29-43.

https://doi.org/10.4236/ojml.2022.121004

Received: November 17, 2021

Accepted: January 27, 2022

Published: January 30, 2022

Copyright () 2022 by author(s) and Scientific Research Publishing Inc. This work is licensed under the Creative Commons Attribution International License (CC BY 4.0).

http://creativecommons.org/licenses/by/4.0/

\begin{abstract}
Talmy's cognitive-semantic typology divides languages based on how path and manner of motion are generally encoded, but recently some studies have suggested that the original typology needs re-examining either by adding a new type (e.g., Slobin, 2004) or using a cline rather than a two or three-language division (e.g., Ibarretxe-Antouñano, 2009). Furthermore, Matsumoto (2003) has suggested that Talmy's original typology should be founded on the heading of a language, rather than the original terms of satellite and verb. This study observes Persian motion events through this concept to help determine if an intermediate language can neatly fit into a single category when analyzed based on heading, or whether a new cline based on heading should be considered. We compared data from a translation corpus of the short story "A Christmas Carol" using a representative verb-framed and satellite-framed language (i.e., Japanese and English), and found that Persian shares some path encoding tendencies with both English and Japanese, but also has significant differences, which suggest it could perhaps be better described as fitting on a cline of path-salience, rather than simply placed in either category.
\end{abstract}

\section{Keywords}

Cognitive Typology, Event Conflation, Persian, Framing Patterns

\section{Introduction}

Talmy (1985) noted that when linguistically expressing a complex event, two or more simple events are often conceptually combined and encoded into a single macro-event-a phenomenon which he called event conflation. Although Talmy (1985) initially postulated that there are five types of macro-events, the most 
robustly discussed event type is motion. For instance, in the motion event in (1), we can see that down, describes the event of descending, or the path of the motion, while roll expresses the event of rolling, or the manner of motion. According to Talmy's primary studies, the world's languages can be divided into two categories based on which event, the path or manner of motion, is encoded on the main verb. He called languages that encode path on verb roots "verb-framed languages" and languages that encode path on non-verbal elements "satellite-framed languages".

1) The car rolled down the hall

Though Talmy (1985) initially suggested a two-tier system for his event-conflation typology, many researchers have since discovered problematic areas in the typology, and suggested that either a third language type should be added (e.g., Slobin, 2004) or that his typology should be treated more as a cline (e.g., Ibarretxe-Antouñano, 2009; Spring, 2019a). Due to these adjustments to the original typology, many less-studied languages have not been clearly placed in the cline or identified as belonging to one of the given categories. This study seeks to help classify one such understudied language, Persian, through an initial look at its categorization tendencies through translation-comparison data.

\section{Previous Studies}

\subsection{Changes to Talmy's Original Typology}

Since Talmy (1985) developed his original typology, a number of studies have been conducted which examine its cross-linguistic validity and applications. Though it seems to be largely valid for some groups of languages and has been the source of much discussion in the fields of cognitive linguistics and second language acquisition, several studies have suggested the need for revisions to the simple two-tier classification that Talmy (1985) suggested. For example, Slobin (2004) found that not all languages fit neatly into the verb-framed and satellite-framed categories, and instead posits the need for a third type, which he calls "equipollently-framed languages". Equipollently-framed languages encompass languages in which "path and manner are expressed by equivalent grammatical forms". One example given is Thai, which encodes both path and manner equally in verbs.

Slobin (1987) led to many studies that argue languages cannot be clearly divided into these framings. For example, Ibarretxe-Antouñano (2009) noted that although Slobin (2004: p. 238) argues "languages cannot be compared on the basis of their accessibility to the semantic component of path", languages can be compared on the basis of their degree of elaboration of path. Specifically, some languages describe this semantic component more often and in much more detail than others. Thus, Ibarretxe-Antouñano (2009) proposed, a cline of path salience that cross-cuts the three lexicalization patterns and classifies languages along a continuum between two ends: high-path-salient languages and low-pathsalient languages. 
Another reimagining of Talmy's (1985) was conducted by Beavers et al. (2010), who questioned the validity of a hard typology due to the fact that most languages may show both verb- and satellite-framed patterns, or even more equipollent-framing patterns.

They further suggested that the tendency towards any single conflation pattern could best be explained by the available resources that exist in a given language and mental economy, rather than cognitive focus. Therefore, it is possible for a verb-framed language to show satellite-framed expressions and vice versa, and furthermore, for various languages to contain equipollently-framed expressions, as exemplified by the Japanese phrases in Beavers et al. (2010), repeated as (2), below.

2) John-wa eki-ni itta.
John-Top station-to went
"John went to the station."
b) John-wa eki-ni hashitte-itta.
John-Top station-to running-went
"John went running to the station."
c) John-wa eki-made hashitta.
John-Top station-until ran
"John ran to the station."
d) John-wa hashitte eki-ni
John-Top running station-to went
"John went to the station running."

(originally taken from Yoneyama, 1986: p. 2, Ex. 4)

Beavers et al. (2010) suggest that (2c) has a higher processing burden than (2b) because in ( $2 b)$ the particle "ni" is used as the same as (2a). However, in (2c) particle "made" adds extra information regarding to boundary-crossing. Moreover, $(2 \mathrm{~d})$ encodes motion event in two clauses that need more processing burden for creating extra clause. Therefore, they claim that ( $2 \mathrm{a}$ and $\mathrm{b}$ ) are easier to process. Furthermore, they suggest that Talmy's typology is not actually due to cognitive factors because they believe that preferences for framing patterns can be explained by the fact that speakers of a language will simply use the most economical resources available to them. However, Spring and Ono (2014) point out that native speakers often do not actually use the lowest economical processing patterns available to them. Specifically, they showed that children already have their tendencies hard-wired from a very young age and generally do not grow out of them even if much more economical resources are given to them later in life by examining the phenomenon of path doubling-the unnecessary repetition of the same path information both inside and outside the main verb.

Another study that attempts to refine Talmy's typology is Matsumoto (2003). Matsumoto (2003) claims that Talmy's typology of verb- and satellite-framed languages suffers from the misleading use of the term "verb". He argues that what is meant by the term verb-framed is in fact a matter of framing the "head of a clause". For example, Matsumoto (2003) points out that satellites can also be 
verbs, as in Japanese, exemplified in (3). In (3), both aruite (walk) and watat-ta (crossed) are verbs, but Matsumoto (2003) classifies aruite as a participle, and watat-ta as the head of the clause, which he argues allows this construction to be verb-framed (or head-framed as he calls it).
3) Taro wa
kawa o aruite
watat-ta
Taro Top river Acc walk
cross-Pst

"Taro walked across the river."

(Matsumoto, 2003: p. 404, Ex. 6)

Furthermore, it must also be noted that Matsumoto (2003) mentioned that all satellites are nonheads, but not all nonheads are satellites. For example, Matsumoto (2003) argues that prepositions could not be considered satellites under Talmy's (1985) original typology because they are not in a sister-relationship to the verb. He uses (4) to show that prepositions function similarly to satellites and can be called nonheads, which is a helpful distinction as evidenced by the fact that Talmy (2009) himself has since admitted that prepositions could also be considered to be satellites. For these reasons, he suggests that a better name for satellite and verb-framed languages are nonhead-framed and head-framed languages respectively.

4) John walked through the building.

(Matsumoto, 2003: p. 408, Ex. 12)

\subsection{Persian and Motion Events}

Hamedi Shirvan and Sharifi (2014) investigated satellites in Persian according to Talmy's definition. They distinguished that satellites can be classified in two ways. The most obvious type of satellite is verbal prefixes which were more common in the past, but still exist in modern Persian such as, andar "into", bāz "backward", bar "down to up", farāz "forward", forud "up to down", furu "down". These prefixes signify the direction of motion and in terms of formal criteria, they are dependently linked to the verbs that they are affixed to. The second type of satellite in Persian is the verb assistant elements in Persian compound verbs. For example, in (5a), although the verb afräštan "raise" signifies the down to up path in root verb, the prefix bar "down to up" emphasizes the direction and adds the extra direction. Moreover, in (5b) nazdik "near" is a verb assistant which encodes the figure $\mathrm{U}$ " $\mathrm{S} / \mathrm{he}$ " is getting close to the ground "house" and the verb šod "become" is the verb which is a light verb that by itself cannot encode path.

5) a) $U$ parčam-rā bar-afrāšt $\mathrm{S} / \mathrm{He} \quad$ flag-Acc "S/He raised the flag."
b) $\mathrm{U}$ be-xāne nazdik-šod
$\mathrm{S} / \mathrm{He} \quad$ to-house near-become.Pst.3Sg
"S/He approached the house."

Furthermore, according to Hamedi Shirvan and Sharifi (2014), verb assistant elements can be further categorized into two classes as follows: 
I) Verb assistant elements that encode path

bālā "up", pāyin "dwon", nazdik "near", dur "far", etc.;

II) Verb assistant elements that encode manner of motion

šenā-kardan "swim-do", reže-raftan "march-go", piyāde-raftan “on foot-go" etc.

Feiz (2011) argued that Persian cannot be neatly categorized as either verb- or satellite-framed, using a discourse-analysis comparison of English and Persian expressions of motion. She notes that the serial-framed pattern in Persian is interesting because manner verbs in the Persian narratives in her study are few in number and generally encode self-contained motion, unless they appear in conjunction with the verb raftan "to go". This is a phenomenon that is generally observed in serial-verb languages, e.g., Thai, which are generally considered to be equipollently-framed languages according to Slobin (2004) or in the middle of the cline of framing (e.g., Ibarretxe-Antouñano, 2009; Spring, 2019a). However, the existing manner verbs in Persian are generally found in light verb constructions (LVCs) where the concept of manner is conveyed through a combination of the semantics of the components of the LVC. Although Feiz (2011) and other researchers have mentioned that Persian has mixed framing characteristics, Postvan et al. (2015) argue that the Persian language does not show the characteristics expected of satellite-framed languages, and considering the mapping of the path component, is best described as a verb-framed language. However, the aforementioned studies are generally based on theoretical linguistics, and as such do not have much empirical data. This can be problematic because, as pointed out by studies such as Ibarretxe-Antouñano (2009), Slobin (2004) and Spring (2019a), Talmy's typology might be best described as a cline, rather than a hard two category classification, but in order to categorize languages across this cline, data is required to show to what degree verb-framed patterns are generally used by native speakers or "colloquial" as Talmy (1985) put it.

\subsection{Translation Comparison Studies}

Though many studies involving motion events look at spontaneous speech and video descriptions (e.g., Slobin, 2004; Spring \& Ono, 2014), comparative translation studies have long been a helpful tool for observing the tendencies of particular groups of native speakers, (e.g., Ono, 2004; Slobin, 2005). For example, Slobin (2005) expanded on his previous works using narration (i.e., Slobin, 2004) to look at comparisons of translated works, focusing on typological factors that seem to shape the "rhetorical styles" in the narratives. The results about manner reveal that "the diversity of the English original is matched or surpassed by the satellite-framed translations, but not by the verb-framed translations" (Slobin, 2005: p. 9). He concluded that this comparison offered more evidence for his (Slobin, 2004) argument that there are different degrees of manner descriptions across languages.

Another study stemming from Slobin's work is Ibarretxe-Antouñano (2003, 2004). Ibarretxe-Antouñano (2003) shows intra-typological differences by com- 
paring translation, and Ibarretxe-Antouñano (2004) further shows though Basque is a verb-framed language, speakers usually offer more complex and detailed descriptions of the path of motion than speakers of other verb-framed languages. For example, in Basque, a single verb with an ablative- and allative-marked noun encodes source and goal respectively to convey more path detailed information, which makes Basque is a high-path salient language according to Ibarretxe-Antouñano's (2009) cline.

Similarly, Ono (2004) investigated the motion events in both English and Japanese translations. Ono (2004) reports that he confirms the notion of Slobin (1996) and Ohara (2002) which suggest that there are differences in the translations of English (satellite-framed) and Japanese (verb-framed). For example, in Japanese to English translations, path verbs were used 72 percent of the time in Japanese but only 47.8 percent in English, and for English to Japanese translations, path verbs were used only 33.3 percent of the time in English but were used 59.3 percent of the time in Japanese. In summary, comparative translation studies have been helpful in categorizing languages or placing them along the cline by providing empirical evidence of trends in languages' event conflation strategies.

\subsection{Research Questions}

Based on the aforementioned studies, it is unclear where Persian lies in the cline of event conflation, in part because of a lack of empirical data. Assuming that there is some degree of cline in the framing of motion events, a comparative translation study of Persian with two languages at the far ends of the spectrum could help to place it. This study therefore chooses to compare it to English and Japanese, as a number of previous studies have suggested that languages such as Japanese, Korean, and Mongolian tend to be even more heavily verb-framed than the romance languages, and many of the Germanic languages tend to be amongst the most satellite-framed (e.g., Matsumoto, 2003; Ohara, 2002; Ono, 2004; Slobin, 1996; Slobin, 2004; Spring, 2019a; 2019b; etc.). Accordingly, this study seeks to give a clear view of the framing tendencies of Persian speakers through a comparative translation analysis to answer the following research questions:

1) Are Persian translations more similar to English, Japanese, or somewhere in between?

2) Can Persian be classified neatly as satellite-framed, verb-framed, or equipollently-framed language, or is it evidence that a cline is a more apt description of Talmy's typology?

\section{Methods}

In the current study we utilized the short story "A Christmas Carol" (Charles Dickens) which was originally written in English because it has been translated into various languages including Persian and Japanese. "A Christmas Carol" is the story of Ebenezer Scrooge who is visited by the ghost of his former business 
partner and the sprits of Christmas Past, Present, and yet to come. This visit causes a journey which include many motion events that is suitable for this study. We examine the motion events focusing on the main-event (path), following Ibarretxe-Antouñano (2009), comparing Persian with English and Japanese in order to examine the position of the Persian language and determine if it can neatly fit in a category or provides evidence for the necessity of a cline. Furthermore, this study adopts Matsumoto's (2003) revision of the term satellite and therefore utilizes the terms "nonhead" and "head" in order to cover a broader range of path coding positions. We make a further distinction between "direction" and "path" and further categorize the types of path into three different path components according to Talmy (2000): vector, conformation, and deictic. Additionally, we divide the vector category into three subcategories: path phase leading from a source (from), leading to a goal (to), or one in between (via). These three subcategories refer to three basic types of motion-arrival, traversal and departure-and are indicated in this study through the terms source, via, and goal.

Direction may be further expressed with respect to the path. For instance, down indicates that a figure's movement is downward. Therefore, there is a difference between path with specific direction as opposed to path with no specific direction e.g., cross. As noted by Matsumoto \& Tanaka (1997) words like up and down are tricky to classify as if they don't have any object they should be concerned a direction. However, some argue that "up the slope" has an object and therefore should be concerned a path. In this study, we do not make such a distinction and simply consider both to be a direction. In the present study, motion verbs are divided into two main categories, "direction" and "path", followed by three subcategories. "NH" designates nonhead, including adpositons, prefixes, verb assistances, "NHH" (nonhead/head) refers to direction or path that is doubly marked on non-verbal elements, and " $H$ " stands for "head", i.e., the verb in the clause that takes a path meaning such as "enter", residan "arrive", deru "exit" in English, Persian, and Japanese respectively.

NHH, also called "path doubling" by Spring and Ono (2014) appear both in English and Persian; e.g., rose up in English and bar-afrāštan in Persian. However, path doubling does not appear to be a norm and is limited to a couple of verbs in Persian. For example, the prefix bar encodes upward direction and the verb afrāštan shows the upward direction as well. Moreover, "NH" in the path can be divided into 3 subdivisions: source " $\mathrm{S}$ ", via "V", and goal "G". In this study, deictic verbs are categorized as being in the direction group since deictic motion verbs refer to motion with respect to a deictic center, rather than motion that has a certain path (Verkerk, 2014). Moreover, Matsumoto \& Kawachi (2020: p. 12) argue that "deixis is in fact a vector plus a special ground, and in this sense, it is conceptually different from Path. In fact, deictic expressions exhibit a set of behaviors distinct from the expressions of directions (e.g., UP), vector (e.g., To), or vector plus conformation (e.g., INTO)".

76 sentences which contained both boundary and non-boundary crossing 
transitional motion events were examined in this study. The reason both boundary and non-boundary crossing events are included is that it has been noted to affect the selection of particular types of path description within a language (e.g. Aske, 1989; Hendriks \& Hickmann, 2015; Spring, 2021; etc.).

\section{Results}

The strategies of each language (English, Japanese, and Persian) with regard to how they encode path in the 76 sentences analyzed from "A Christmas Carol" are represented in Table 1 . The results show that there are slightly different tendencies in the three languages depending on whether the motion expressions were direction or path type.

For directional motion, Persian utilizes NH expressions far more than English or Japanese. A chi-square test revealed that for direction, there was a significant difference in the amount of heading-framed sentences in English, Persian, and Japanese as opposed to non-heading or non-heading-heading framed sentences; $\chi^{2}(2, N=175)=20.848, p<0.001$. Since Japanese is a head-framed language it tends to encode direction on the root verb, but English and Persian tend to encode direction on the non-head. More specifically, $\mathrm{NH}$ accounts for 15 cases in English and 8 cases in Japanese. In the case of Persian, however, $\mathrm{NH}$ accounts for 27 cases, nearly 2 times more than English and three times more than Japanese. (6) through (8) are the examples of direction's nonhead encoding.

6) Some shaggy ponies now were seen trotting towards them with boys upon their backs. p. 48

7) Eskruj be-samt-e panjare david va ān-rā gošud.p. 164 Scrooge to-toward-Ez window run.Pst.3Sg and that-Acc open.Pst.3Sg "He ran to the window and opened it."

8) Sukuruuji-wa isoide beddo-kara dete tesagurishinagara madobe-e Scrooge-Top hurry bed-from exit while groping way window-Dir itta. p. 42 go.Pst

Table 1. Number (percentage) of path encoding styles in English, Persian, and Japanese.

\begin{tabular}{|c|c|c|c|c|c|c|c|c|c|c|}
\hline \multirow[b]{3}{*}{ languages } & \multicolumn{4}{|c|}{ Direction } & \multicolumn{6}{|c|}{ Path } \\
\hline & \multirow{2}{*}{$\mathrm{NH}$} & \multirow{2}{*}{$\mathrm{NHH}$} & \multirow{2}{*}{$\mathrm{H}$} & \multirow{2}{*}{ Total } & \multicolumn{3}{|c|}{$\mathrm{NH}$} & \multirow{2}{*}{$\mathrm{NHH}$} & \multirow{2}{*}{$\mathrm{H}$} & \multirow{2}{*}{ Total } \\
\hline & & & & & S & $\mathrm{V}$ & G & & & \\
\hline English & $\begin{array}{c}15 \\
(27.7)\end{array}$ & $\begin{array}{c}0 \\
(0)\end{array}$ & $\begin{array}{c}39 \\
(72.2)\end{array}$ & 54 & $\begin{array}{c}5 \\
(5.5)\end{array}$ & $\begin{array}{c}28 \\
(31.1)\end{array}$ & $\begin{array}{c}41 \\
(45.5)\end{array}$ & $\begin{array}{c}3 \\
(3.3)\end{array}$ & $\begin{array}{c}13 \\
(14.4)\end{array}$ & 90 \\
\hline Persian & $\begin{array}{c}27 \\
(45.7)\end{array}$ & $\begin{array}{c}3 \\
(5)\end{array}$ & $\begin{array}{c}29 \\
(49.1)\end{array}$ & 59 & $\begin{array}{c}20 \\
(19.6)\end{array}$ & $\begin{array}{c}35 \\
(34.3)\end{array}$ & $\begin{array}{c}33 \\
(32.3)\end{array}$ & $\begin{array}{c}0 \\
(0)\end{array}$ & $\begin{array}{c}14 \\
(13.7)\end{array}$ & 102 \\
\hline Japanese & $\begin{array}{c}8 \\
(12.9)\end{array}$ & $\begin{array}{c}0 \\
(0)\end{array}$ & $\begin{array}{c}54 \\
(87)\end{array}$ & 62 & $\begin{array}{c}7 \\
(6)\end{array}$ & $\begin{array}{c}23 \\
(20)\end{array}$ & $\begin{array}{c}28 \\
(24.3)\end{array}$ & $\begin{array}{c}0 \\
(0)\end{array}$ & $\begin{array}{c}57 \\
(49.5)\end{array}$ & 115 \\
\hline
\end{tabular}

$\mathrm{NH}=$ nonhead, $\mathrm{NHH}=$ nonhead-head, $\mathrm{H}$ = head, $\mathrm{S}=$ source, $\mathrm{V}=\mathrm{Via} /$ traversal, $\mathrm{G}=$ goal/vector. 
"He scrambled out of bed, and groped his way to the window."

The next subcategory of direction is "NHH", which was only observed in Persian. It accounts for 3 cases which had one token. The verb barxāstan has two parts, the prefix bar "move up" and the verb xāstan which also means "move up". These two parts together means "rise or stand up". Thus, direction is encoded in both nonhead and head.

9) Fezivig-e pir bā-šuronešāti heyratangiz az-pošt-e miz-e

Fezziwig-Ez old with exciting joy incredible from-behind-Ez desk-Ez

boland-aš barxāst.p. 71

high-Enc.3Sg rise.Pst.3Sg

"Fezziwig, skipping down from the high desk."

The final subcategory of direction, $\mathrm{H}$, represents those verbs that encode specific direction, including deictic verbs. There are 39 cases in English, 29 cases in Persian, and 54 cases in Japanese. One potential reason Japanese that has a higher number of cases is that Japanese allows complex verb phrases in which a deictic verb is encoded on a different slot and thus, there is less competition between manner, path, and deictic verbs as in English (Spring, 2019b). In the English sentence (10a) rose shows the upward direction as in 12 Japanese verb agaru (rise). Moreover, come in 10b, ämadan (come) in 11, and iku (go) in 12 shows deictic center.

10) a) The Ghost of Christmas Present rose. p. 79

b) when it came near him, Scrooge bent down upon his knee. p. 123

11) šomā hič vaqt be-didan-e man na-yāmadid.p. 20 you never time to-see.Inf-Ez me Neg-come.Pst.2Pl "You never came to see me."

12) Bobu-wa ima-wo dete 2kai-ni agatte-itta. p. 129 Bob-Top living room-Acc leave 2floor-to ascend-go.Pst

"He left the room, and went upstairs into the room above."

With regards to path types of motion, it seems that English and Persian were observed to be similar to each other in terms of whether or not path is encoded on heads, but dissimilar from Japanese, as evidenced by a chi-square test of the amount of heading and non-heading found in this category; $\chi^{2}(2, N=307)=$ 45.6242, $p<0.001$. According to the data in Table 1 , head-framing was used much more extensively in Japanese (i.e., nearly 50\% of all sentences), while English and Persian use this encoding style in less than $15 \%$ of sentences. Representative examples of this type of framing include sentences (13) and (14), in which English and Persian encode the path on the verbs left and resāndan (to reach), respectively. It is worth mentioning that encoding path in simple verbs is not the only way for these languages to employ $\mathrm{H}$ encoding. As can be seen in (15), the Japanese utilizes a compound verb (V1-V2), in which V1 encodes manner and V2 encodes path.

13) His nephew left the room without any angry word. p. 11

14) Eskruj jastoxizkonān $x^{\mathrm{v} o d-r a ̄ ~ b e-o t a ̄ q-e ~ n e s ̌ i m a n ~}$ 


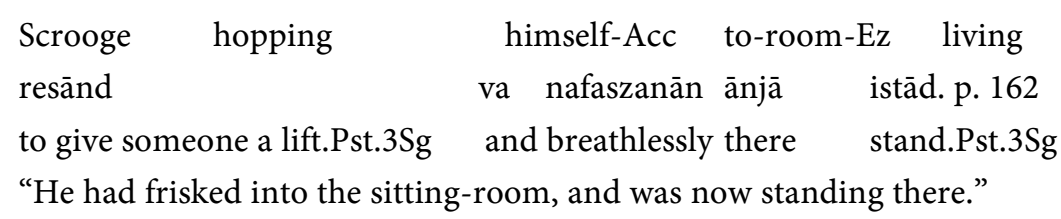

15) Sukuruuji-wa butsubutsu monku-wo iinagara ayumi-satta. p. 23 Scrooge-Top grumble complaint-Acc while saying walk-leave.Pst

"Scrooge walked out with a grow."

Furthermore, Persian shows a much stronger tendency to use source expressions than either English or Japanese, as evidenced by a chi-square test of the various path type non-head subcategories; $\chi^{2}(2, N=220)=10.27, p=0.03$. Specifically, path types of motion are also divided into 3 subcategories of non-head expressions (i.e., source, via, and goal), which were utilized differently in the three languages. What is noteworthy here is that Persian prefixes and verb assistants, discussed in section 2.2, are included as via because they encode path on non-heads elements. The results indicated that English shows a tendency to use goal and via styles of non-heads but not source non-heads. In comparison, Japanese shows a similar trend to use goal and via styles of non-heads more than source non-heads, but it does not use them as much as English. Finally, Persian differs from both languages in that uses source non-heads much more than either English or Japanese, and uses goal non-heads to a degree that is halfway between Japanese and English. Some examples of representative such encodings are given below.

16) So she came out prematurely from behind the closet door and ran into his arms. p. 90

17) Saranjām bačče-hā bā-ḥayejān-hā-ye-šān betadrij az-otāq eventually child-Pl with-enjoy-Pl-Ez-Enc.3Pl gradually from-room $\begin{array}{lll}\text { xārej-šodand be-țabaqe-ye bālā-raftand... } & \text { p. } 81\end{array}$ exit-become.Pst.3Pl to-floor-Ez up-go.Pst.3Pl

"It is enough that by degrees the children and their emotions got out of the parlor and by one stair at a time, up to the house."

18) a) Hayabaya-to oshiire-no tobira-no kage-kara tobidashi chichioya-no quickly closet-Gen door-Gen back-from run.out father-Gen ude-ni tobi-konda. p. 86 arm-Dat jump in.Pst "so she came out prematurely from behind the closet door and ran into his arms"

b) Futari-wa michi-nisotte aruita. Two person-Top road-along walk.Pst "They walked along the road."

In (16) from, into, and out encode source, goal, and via of the path respectively. Moreover, in (17) Persian encodes source with az (from), goal with the vector preposition $b e$ (to) and via or path in the verb assistant $x a \bar{r} r e j$ (exit) which has a sister relationship with the light verb šodan (become). As can be seen in (18-a), Japanese has some postposition that encodes source, via, and goal. Spe- 
cifically, kara (from) encodes source and indicates the start of movement and $n i$ (to) encodes the goal or vector. Also, in (18-b) via is encoded by complex postposition that is derived from the verb sou (to move along a set path) that shows the length of path. In all above examples, the source, via or path, and goal are encoded on head-external elements. The next sub category is $\mathrm{NHH}$ which is observed in English and accounts for 3 cases. The verb pass encodes the path and the particle through encodes the via.

\section{Discussion}

The results of this study suggest that while English and Japanese fit neatly into Talmy's (1985) originally suggested typology of satellite- and verb framed-languages, Persian does not. First, it seems that Persian is not as clearly satellite-framed as English. In most cases, manner of motion is conflated into verbs in English and path is encoded on satellites or head-external elements. Due to this feature, English can encode several path segments on satellites that come with one verb in one clause. As noted by Spring (2019b), English speakers find sentences in which both deictic information and manner of motion information are encoded in the same clause extremely unnatural, and thus there is competition for the verb slot. Moreover, English is tightly packed. However, Persian cannot encode several satellites with one motion verbs because satellites are encoded in prefixes and verb assistants. Therefore, Persian like other verb-framed languages utilizes several verbs that can be either path verbs or verbs with satellite. Hence, Persian needs several grounds for each verb.

20) He fastened the door, and walked across the hall, and up the stairs; slowly too; trimming his candle as he went. p. 21

$\begin{array}{lllll}\text { 21) U dar-rā } & \text { bast } & \text { az-rāhro } & \text { gozašt } & \text { va barāye } \\ \text { he door-Acc } & \text { close.Pst.3Sg from-hall } & \text { pass.Pst.3Sg and for } \\ \text { jologiri } & \text { az-xāmuš-šodan-e } & \text { šam' xeyli àheste } \\ \text { prevention } & \text { from-snuff-become.Inf-Ez candle very } & \text { slowly } \\ \text { az-pelle-hā } & \text { bālā-raft.p.32 } & & \\ \text { from-stair-Pl } & \text { up-go.Pst.3Sg } & & \end{array}$

In English, satellites are prepositions and particles which are can be considered to be non-heads. Conversely, Persian has a more robust well of satellites to use in motion expressions: prepositions, prefixes, and verb assistants which are nouns, adjectives, and adverbs. Furthermore, prepositions in Persian can be divided into two groups: "bare prepositions and ezāfe prepositions (those which are always used in the genitive case). Following are lists of the preposition used in motion expressing, divided according to whether express vector of motion or conformation" (Babai, 2011: p. 159). The vector prepositions which are bare prepositions are $a z$ (from), $b e$ (to), and $t \bar{a}$ (until). What is interesting here is that except one case, these prepositions can lose ezāfe and then be combined with verbs to make a compound verb. Persian's prepositions, like English, can encode (source, direction, goal) in motion events. Therefore, path segments are distributed on prepositions and satellites that make path more notable. 
Furthermore, it is clear that Persian does not follow the same tendencies as Japanese. For example, there are clear differences in how the two languages encode middle path. In Japanese, middle path is encoded with the accusative case marker wo, while Persian, except in one case in my data, generally utilizes the source marker $a z$ (from). This might be related to the differences of cognitive concepts or verb meanings, but further research is necessary to know for sure.

22) They pass through the wall. p. 46

23) Futari-wa kabe-wo toori-nuketa. p. 47 two people-Top wall-Acc pass through.Pst

24) Ān-do az-divār gozaštand. p. 58 that-two from-wall cross.Pst.3Pl

Moreover, the results show that the Japanese data contains more path verb types than English and Persian. It is worth noting that English path verbs are loaned from French and other Romance languages, and according to the data, simple verbs are used even less frequently in Persian simple verbs than the other two languages. It should also be mentioned that some verbs like sarzadan observed in the data, is a made of nonverbal element sar (head) and light verb zadan (hit). Unlike other satellites which encode path, sar by itself cannot encode path and is semantically dependent on the light verb to show a motion event. Thus, sarzadan is categorized as path verb and no satellite or nonhead. Although, in the data of this study path verbs are almost 3 times less frequently used in Persian than Japanese, according to Shah Hosseini et al. (2016) middle Persian tended to utilize path verbs more than modern Persian. Thus, it might be that Persian lost the strong tendency to use path verbs, which could potentially be explained by the emergence of light verbs which can combine with a wide array of words such as nouns, adjectives, adverbs to make new path verbs.

One surprising finding in this study is the tremendous usage of deictic verbs in the three languages. For one, English utilizes deictic verbs almost as frequently as Persian. This could be because of the inherent competition for the verb-slot between deictic information and manner of motion information in English (Spring, 2019b), so if deictic information was important to the story, it is likely that deictic verbs would be used instead of manner of motion verbs. As mentioned above, due to the lower frequency and type of path verbs in English and Persian, when path verbs were used in these two languages, it was usually a deictic verb. In the case of Persian, complex manner verbs consist of nonverbal elements that combine with deictic verbs, which might also partially explain the large number of deictic verbs found. However, in Japanese which is a verbframed-languages, deictic verbs are much more common because they often are part of serial verbs. On common pattern was for deictic verbs to appear together with verbs that encode direction or path. However, in Japanese, when manner of motion is encoded in a verb, it also usually contains a deictic verb, following the pattern "manner verb (-te form) deictic verb". Here it is worth noticing that according to Talmy (2000), go describes motion from the deictic center, whereas come describes motion toward the deictic center. However, there are some lan- 
guage-specific restrictions. For instance, when describing how the speaker is moving toward the addressee, the addressee can be the "center" in English and Persian, but not in Japanese.

\section{Conclusion and Implications}

In summary, the results show that in English and Persian, non-head-framing was used more, while in Japanese the head-framing was the prominent pattern. Therefore, while the data of this study supports the notion that Japanese can be safely considered a verb-framed language, it seems that both English and Persian translations were significantly different, and therefore should not be classified as verb-framed. However, this does not necessarily mean that Persian should be classified as a satellite-framed language, because it did also exhibit striking differences from English. For example, the frequency of source descriptions in Persian, was two times greater than English and Japanese. Furthermore, for encoding traversal path satellites or non-heads, Persian also employs a number of non-prototypical patterns for satellite-framed languages such as are prefixes and verb assistants. Furthermore, there are a few simple verbs that encode path on the root verbs which causes Persian to exhibit some features more congruent with verb- or head-framed languages. Moreover, Persian seems to have mixed tendencies in that it often encodes source and vector in prepositions, but utilizes both non-head and head framing for encoding direction. Therefore, though the results of this study agree with previous studies that English and Japanese could be classified as satellite- and verb-framed languages (e.g., Ono, 2004; Ohara, 2002; Spring, 2019a; Yoneyama, 1986), it seems that Persian does not clearly fit into either category so easily.

Since this study focused on the main event. i.e., path, it would seem that Persian would better fit somewhere in the middle of a cline based on path descriptions, as described by Ibarretxe-Antouñano (2009). However, the current study does have some limitations, namely that it focused on the main event. Similar research should be conducted on Persian that instead focuses on the co-event, i.e., manner of motion, as such data would help provide new evidence of Persian's conflation tendencies and Perhaps help place it more clearly towards one end of the cline or the other. Another limitation to this study is that it utilizes only one, limited set of data, and thus more research is still required to refine the findings of this study. Future studies should expand one by including more modern translation comparisons, other types of event description data (e.g., video description), and also looking specifically at the manner of motion encoding tendencies. Furthermore, typological differences between satellite and verbframed languages can lead speakers of satellite-framed and verb-framed languages to select one pattern over the other in actual language use that affect the narrative rhetorical styles, which can lead to misunderstandings and unnatural expressions that are very difficult to overcome (e.g. Cadierno, 2010; Spring, 2019a). Therefore, we suggest that these differences be taught specifically to speakers of languages in this study who are learning a second language of a dif- 
ferent type. However, how to specifically teach these differences and what impact that has on second language acquisition will be left to future studies.

\section{Conflicts of Interest}

The authors declare no conflicts of interest regarding the publication of this paper.

\section{References}

Aske, J. (1989). Path Predicates in English and Spanish: A Closer Look. Proceedings of the Berkeley Linguistics Society, 15, 1-14. https://doi.org/10.3765/bls.v15i0.1753

Babai, H. (2011). Lexicalization of Motion Event in Persian. Theory and Practice in Language Studies, 1, 157-162. https://doi.org/10.4304/tpls.1.2.157-162

Beavers, J., Levin, B., \& Tham, S. W. (2010). The Typology of Motion Expressions Revisited. Journal of Linguistics, 46, 331-377. https://doi.org/10.1017/S0022226709990272

Cadierno, T. (2010). Motion in Danish as a Second Language: Does the Learner's L1 Make a Difference? In Z. Han, \& T. Cadierno (Eds.), Linguistic Relativity in SLA (pp. 1-33). Multilingual Matters. https://doi.org/10.21832/9781847692788-003

Feiz, P. (2011). Traveling through Space in Persian and English: A Comparative Analysis of Motion Events in Elicited Narratives. Language Sciences, 33, 401-416. https://doi.org/10.1016/j.langsci.2010.10.010

Hamedi Shirvan, Z., \& Sharifi, S. (2014). A Typological Analysis of Satellite in the Event Structure of Motion Verbs in Persian. Journal of Language Related Research, 5, 71-89.

Hendriks, H., \& Hickmann, M. (2015). Finding One's Path into Another Language: On the Expression of Boundary Crossing by English Learners of French. The Modern Language Journal, 99, 14-31. https://doi.org/10.1111/j.1540-4781.2015.12176.x

Ibarretxe-Antouñano, I. (2003). What Translation Tells Us about Motion: Acontrastive Study of Typologically Different Languages. International Journal of English Studies, 3, 153-178.

Ibarretxe-Antouñano, I. (2004). Motion Events in Basque Narratives. In S. StrÖmqvist, \& L. Verhoeven (Eds.), Relating Events in Narrative: Typological and Contextual Perspectives (pp. 89-112). Lawrence Erlbaum Associates.

Ibarretxe-Antouñano, I. (2009). Path Salience in Motion Events. In J. Guo, E. Lieven, N. Budwig et al. (Eds.), Crosslinguistic Approaches to the Psychology of Language: Research in the Tradition of Dan Isaac Slobin (pp. 403-414). Psychology Press.

Matsumoto, Y. (2003). Typologies of Lexicalization Patterns and Event Integration: Clarifications and Reformulations. In S. Chiba et al. (Eds.), Empirical and Theoretical Inves tigations into Language: A Festschrift for Masaru Kajita (pp. 403-418). Kaitakusha.

Matsumoto, Y., \& Kawachi, K. (2020). Broader Perspectives on Motion Event Descriptions. John Benjamins. https://doi.org/10.1075/hcp.69

Matsumoto, Y., \& Tanaka, S. (1997). Kuukan to idou hyoogen [Expression of Space and Motion]. In M. Nakau (Ed.), Nichi-eigo hikaku sensho (pp. 128-153). Kenkyusha.

Ohara, K. H. (2002). Linguistic Encodings of Motion Events in Japanese and English: A Preliminary Look. The Hiyoshi Review of English Studies, 41, 122-153.

Ono, N. (2004). Ido hyogen no nichiei hikaku: shosetsu to sono honyaku o daizai ni [A Comparison of Motion Expressions in Japanese and English: Using Novels and Their Translations]. In S. Sato, K. Horie, \& W. Nakamura (Eds.), Taishoo Gengogaku no 
Shintenkai (pp. 3-26). Hitsuji Shobo.

Postvan, H., Haqbin, F., \& Afrashi, A. (2015). Representation of Motion Events in Persian-Speaking Children's Narratives. Jastarhaye Zabani, 24, 19-44.

Shah Hosseini, F., Roshan, B., Saburi, N., \& Najafiyan, A. (2016). Barresiye tatbiqye afale masirnamaye zabanhaye Farsiye miyane va no [A Comparative Study of Path Verbs in Middle and Modern Persian Languages]. Pazhuhesh Zaban va Adabiyat Farsi [Persian Language and Literature Research], 42, 167-193.

Slobin, D. I. (1987). Thinking for Speaking. Annual Meeting of the Berkeley Linguistics Society, 13, 435-445. https://doi.org/10.3765/bls.v13i0.1826

Slobin, D. I. (1996). Two Ways to Travel: Verb of Motion in English and Spanish. In M. Shibatani, \& S. A. Thompson (Eds.), Grammatical Constructions: Their Form and Meaning (pp. 195-219). Oxford University Press.

Slobin, D. I. (2004). The Many Ways to Search for a Frog: Linguistic Typology and the Expression of Motion Events. In S. Strömqvist, \& L. Verhoeven (Eds.), Language in Mind: Advances in the Study of Language and Thought (pp. 219-257). MIT Press.

Slobin, D. I. (2005). Relating Narrative Events in Translation. In D. Ravid, \& H. B. Shyldkrot (Eds.), Perspectives on Language and Language Development: Essays in Honor of Ruth A. Berman (pp. 115-129). Kluwer. https://doi.org/10.1007/1-4020-7911-7_10

Spring, R. (2019a). From Linguistic Theory to the Classroom: A Practical Guide and Case Study. Cambridge Scholars Publishing.

Spring, R. (2019b). Proposal of a Hierarchy for Manner Salience Affecting Motion-Framing Choices in English: At What Point Did I Make This Weird? In Proceedings of the 35th Annual Conference of the English Linguistic Society of Japan (pp. 175-181). Kaitakusha.

Spring, R. (2021). Factors Influencing Motion Event Categorization Choices in NonLinguistic Tasks: The Effects of Manner Noticeability and Boundary Crossing on English and Japanese Speakers. Journal of Studies in Language Sciences, 19, 19-34.

Spring, R., \& Ono, N. (2014). Path Doubling: Evidence for the Existence of Prototype-Schema in Motion Event Framing Choices. Journal of Studies in Language Sciences, 13, 166-191.

Talmy, L. (1985). Lexicalization Pattern: Semantic Structure in Lexical Form. In T. Shopen (Ed.), Language Typology and Syntactic Description Vol. 3 (pp. 36-149). Cambridge University Press.

Talmy, L. (2000). Toward a Cognitive Semantics: Typology and Process in Concept Structuring. MIT Press. https://doi.org/10.7551/mitpress/6848.001.0001

Talmy, L. (2009). Main Verb Properties and Equipollent Framing. Crosslinguistic Approaches to the Psychology of Language. In J. Guo, E. Lieven, N. Budwig, S. Ervin-Tripp, K. Nakamura, \& S. Özçalışkan (Eds.), Research in the Tradition of Dan Isaac Slobin (pp. 389-402). Psychology Press.

Verkerk, A. (2014). Where Alice Fell into: Motion Events from a Parallel Corpus. In B. Szmrecsanyi, \& B. Wälchli (Eds.), Aggregating Dialectology, Typology, and Register Analysis (pp. 324-354). De Gruyter. https://doi.org/10.1515/9783110317558.324

Yoneyama, M. (1986). Motion Verbs in Conceptual Semantics. Bulletin of the Faculty of Humanities, 22, 1-15. 